Pamiętnik Literacki 2018, 3, s. 71-82

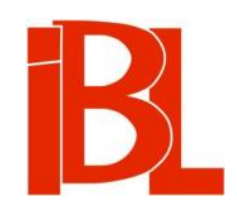

\title{
Objaśnianie marzeń sennych według Stanisława Ignacego Witkiewicza
}

\author{
Fryderyk Nguyen
}




\section{OBJAŚNIANIE MARZEŃ SENNYCH WEDŁUG STANISŁAWA IGNACEGO WITKIEWICZA}

Pod data 11 VIII 1912 Bronisław Malinowski zanotował w swoim Dzienniku: „Dziś w nocy postanowiłem przypomnieć sobie sny wedł $\langle$ ug $\rangle$ rec〈epty $\rangle$ Stasia i rzeczywiście śniłem cały szereg [...]” (MD 160) ${ }^{1}$. Wspomnianym „Stasiem” jest, oczywiście, Stanisław Ignacy Witkiewicz, ówczesny najbliższy przyjaciel przyszłego antropologa. Ta wzmianka bezsprzecznie świadczy o tym, że dla autora Nienasycenia marzenia senne nie były sprawą obojętną. Chociaż nie zachowały się relacje na temat jego własnych (poza kilkoma napomknieniami w listach), pisarz wplótł intrygujące fantazje oniryczne do swoich dzieł powieściowych.

Silne zainteresowanie Witkacego tą sferą życia było prawdopodobnie spowodowane zaznajomieniem się $z$ teorią psychoanalizy. Czy wpłynęła ona jednak na opisy marzeń sennych zawartych w jego powieściach? A jeśli tak, to w jakim stopniu? Czy Witkacy miał również swoją własną wykładnię ich znaczenia? Aby odpowiedzieć na te pytania, trzeba zastanowić się najpierw, co o pracach Sigmunda Freuda wiedział Witkiewicz, gdy wprowadzał oniryczne fantazje do swoich dzieł. Następnie należy zbadać, na czym polegała owa - wzmiankowana przez Malinowskiego - „recepta Stasia” na przypominanie snów i czy była też związana ze sposobem ich utrwalania. Dopiero mając te informacje, można przystąpić do analizy snów zawartych w poszczególnych powieściach Witkacego. Jako że pisarz początkowo sceptycznie podchodził do psychoanalizy, a i później nie w pełni akceptował myśli Freuda, konieczne będzie uchwycenie różnic pomiędzy tym, jaki sens nadawał marzeniom sennym Witkacy, jaki zaś austriacki psychiatra.

Za przedmiot badań obieram najbardziej bogata w treść fantazję oniryczną ze znajdujących się w utworach artysty - sen Genezypa Kapena z Nienasycenia (jedyny zawarty w owej powieści). Konieczna będzie tu lektura przeprowadzona pod kątem metody Freuda. Zamierzam dzięki temu sprawdzić, w jakim stopniu literackie marzenie senne zostało zainspirowane psychoanalizą, a na ile można w nim wyczytać własne refleksje autora.

1 Skrótem tym odsyłam do książki B. Mali now sk i g o Dziennik $w$ ścisłym znaczeniu tego wyrazu (Wstęp, oprac. G. Ku b i c a. Kraków 2007). Poza tym przywołując w tekście artykułu dzieła S. I. W i t ki e w i c z a, posługuję się następującymi oznaczeniami: WD = Dramaty II. Oprac. J. D egler. Warszawa 1998; WN = Nienasycenie. Oprac. J. D e gler, L. S o kół. Warszawa 1996; WNN = Narkotyki. - Niemyte dusze. Oprac. A. M i c iń s ka. Wyd. 2. Warszawa 2004. Cyfry po skrótach oznaczają numery stronic. 


\section{Związki Witkacego z psychoanaliza}

W grudniu 1912 odbył się I Zjazd Neurologów, Psychiatrów i Psychologów Polskich, podczas którego jedną $z$ sesji poświęcono psychoanalizie. Było to istotne wydarzenie dla rozwoju Freudowskich idei w polskiej nauce. Wśród prelegentów znalazł się m.in. zakopiański doktor Karol de Beaurain, który w tym samym roku rozpoczął terapię psychoanalityczną Stanisława Ignacego Witkiewicza, wówczas 27-letniego, początkującego artysty. Lekarz ten nigdy nie otrzymał wykształcenia w dziedzinie teorii psychoanalitycznych - studiował na Uniwersytecie Zuryskim, jeszcze zanim one powstały. Spotkania z Witkacym zakończył w marcu 1913. W tym okresie opublikował artykuł na łamach „Internationale Zeitschrift für ärztliche Psychoanalyse". Potem jednak nie zajmował się już psychoanalizą ${ }^{2}$. Wszystko wskazuje na to, że sesje z młodym Witkiewiczem przypadły na szczególny czas, w którym de Beaurain próbował swoich sił w nowym nurcie psychologii i tworzył na jego gruncie własne koncepcje. Później bowiem zawrócił z tej drogi.

W okresie terapii Witkacy nie był entuzjastycznie nastawiony do metody psychoanalitycznej. W liście do Heleny Czerwijowskiej z 10 III 1913 wspominał, że nie przybyło mu wiary w psychoanalizę, chociaż wciąż chodził do de Beauraina ${ }^{3}$. Niewątpliwie jednak teorie Freuda, przekazane przez doktora, jakiś wpływ na Witkacego wówczas wywarły, skoro zainteresował się on snami i w dodatku chciał nimi zaabsorbować swojego przyjaciela (zob. MD 160). Oczywiście, można się zastanawiać, czy aby na pewno był to efekt sesji u de Beauraina, a nie niezależna ciekawość artysty. Jednakże data pojawienia się w Dzienniku Malinowskiego wzmianki o „recepcie Stasia” na przypominanie snów zbiega się z okresem, kiedy autor Nienasycenia był poddawany psychoanalizie, co każe domniemywać, iż istnieje związek między tymi faktami.

Jak stwierdza Paweł Dybel, w latach młodości Witkacy nie zetknął się z psychoanaliza w postaci czystej, lecz z jej „dzikim” wariantem, przedstawionym mu przez de Beauraina. Doktor dosyć luźno stosował się do założeń Freuda i wprowadzał do terapii swoje własne pomysły, takie jak pojęcie kompleksu embriona, którego dopatrywał się u młodego Witkiewicza, wyśmiewającego później ową diagnozę. To (jak wyrażał się autor Nienasycenia) „węzłowisko” było, według de Beauraina, spowodowane zbyt dużą zależnością pacjenta od ojca ${ }^{4}$.

Mimo specyficznego podejścia lekarza, Witkacy poznał dzięki niemu podstawowe założenia teorii Freuda oraz zaczął spisywać swoje sny ${ }^{5}$. De Beaurain nie tylko analizował pacjenta, lecz także zaproponował mu „kurs praktyczny” psychoanalizy (WNN 151). Zakopiański doktor był wtedy dla Witkacego głównym źródłem wiedzy o nowym wówczas kierunku w psychologii.

2 Zob. L. Magnon e, Psychoanaliza $w$ Polsce? W zb.: Psychoanaliza $w$ Polsce 1909-1946. T. 1: Psychoanaliza i Polacy, psychoanaliza i literatura, psychoanaliza zbiorowości, psychoanaliza kobiet. Wybór, oprac., wstęp ... Warszawa 2016, s. XI-XIII.

3 S. I. Witki ew i c z, Listy I. Oprac., przypisy T. P aw la k. Warszawa 2013, s. 247.

4 Zob. Od Jekelsa do Witkacego. Psychoanaliza na ziemiach polskich pod zaborami 1900-1918. Wybór tekstów. Wybór, układ, wstęp, biogramy B. Dobroczyńs ki, P. Dy bel. Przeł. J. Górny, O. Pieńk ows ka - Kor d e czka. Kraków 2016, s. 619.

5 Zob. ibidem, s. 620. 
Stopniowo artysta przekonywał się do myśli Freuda, czego wyraźnym dowodem jest książka publicystyczna Niemyte dusze, zadedykowana właśnie Karolowi de Beaurainowi ${ }^{6}$. Autor poświęcił w niej wiele miejsca Ernstowi Kretschmerowi, niemieckiemu psychiatrze pozostającemu pod wpływem idei Freudowskich. Witkacy zetknął się z jego dziełem Körperbau und Charakter z 1921 roku. Ze szczerością przyznawał przy tym, że Wstępu do psychoanalizy Freuda nie skończył jeszcze dotąd czytać (WNN 174). Wspominał natomiast i polecał prace Geraldine Coster o tytule Psychoanaliza ${ }^{7}$. Jak pisze Lena Magnone, pozycja ta, choć przyczyniła się do popularyzacji psychoanalizy, referowała jej założenia w sposób uproszczony; łączyła niezgodne ze sobą koncepcje Freuda, Carla Gustava Junga i Alfreda Adlera ${ }^{8}$. W Jedynym wyjściu Witkacy odwoływał się ponadto do 2-tomowego podręcznika Władysława Witwickiego Psychologia ${ }^{9}$. W latach trzydziestych, a więc w okresie powstawania Niemytych dusz, utrzymywał z kolei kontakty z księdzem Henrykiem Kazimierowiczem - kapłanem o wszechstronnych zainteresowaniach, zajmującym się m.in. właśnie psychoanalizą. Ponadto Witkacy miał wiedzę dotyczącą psychoanalizy w wersji Adlera, szczególnie jego koncepcji kompleksu niższości, oraz działań terapeutycznych Junga ${ }^{10}$.

Pisząc Nienasycenie, Witkiewicz mógł już znać część spośród wyliczonych tutaj lektur, na pewno zaś dysponował informacjami o teorii Freuda, jakie uzyskał od doktora de Beauraina. Psychoanaliza musiała więc w jakiś sposób wpłynąć na poglądy pisarza na temat snów. Zastanawiające jednak, czy fantazja oniryczna dogłębnie przedstawiona w Nienasyceniu jest odzwierciedleniem fascynacji tym kierunkiem psychologii, czy też mówi coś o własnych przemyśleniach Witkacego dotyczących natury marzeń sennych.

\section{Recepta Stasia}

Jak twierdzi Grażyna Kubica, edytorka Dziennika Malinowskiego (a za nią Dybel), sposób Witkacego na przypominanie snów wiązał się również z metodą ich zapisu ${ }^{11}$.

$6 \quad$ Witkacy pisze w tej ksią̇ce (WNN 151-152) o swoim dawnym terapeucie:

„Lata całe nie doceniałem tego, co ów pierwszy nieomal pionier freudowskich idei u nas pośrednio dla mnie uczynił.

[...] wyjątkowy ten i nie doceniony u nas człowiek chciał mi dać coś z siebie, ze swojej głębokiej wiedzy o ludziach i życiu, ustokrotnionej potężnym aparatem teorii Freuda, tego również nie wszędzie należycie docenionego, jednego $z$ największych geniuszy i dobroczyńców ludzkości naszej epoki".

7 Zob. S. I. Wit ki ew i z, Jedyne wyjście. Oprac. A. Mi c ińs ka. Warszawa 1993, s. 8. - WNN 174. Chodzi właściwie o książkę G. C o s te r Psychoanaliza w zastosowaniu do ludzi normalnych (Przeł. M. G ó r s ka. Warszawa 1929; oryginał: Psychoanalysis for Normal People. 1926).

8 Magnone, op. cit., s. XLIII.

9 Witkiewicz, Jedyne wyjście, s. 8. Mowa tu o pracy Witwickiego wydanej we Lwowie w latach 1926-1927.

10 Teorię Adlera uważał Witkacy za „potencjalnie zawartą w dziele Freuda” (WNN 198). Zob. też WNN 165.

11 G. Kubic a, wstęp w: MD 147. - P. Dy b e 1, Psychoanaliza - ziemia obiecana? Z dziejów psychoanalizy $w$ Polsce 1900-1989. Cz. 1: Okres burzy i naporu. Poczatki psychoanalizy na ziemiach polskich okresu rozbiorów 1900-1918. Kraków 2016, s. 210. 
Wniosek ten wydaje się nieuprawniony. Malinowski wspomina jedynie o „recepcie Stasia” na „przypominanie snów”, nigdzie nie informując o ich notowaniu. To, że Witkacy instruował przyjaciela tylko o pewnego rodzaju mnemotechnice, potwierdza ustęp z Nienasycenia, w którym główny bohater, Genezyp Kapen, odtwarza w pamięci swoją oniryczną fantazję:

Genezyp zaczą przypominać sobie sen w odwrotnym porzadku w stosunku do jego naturalnego przebiegu. [Bo sen przecie nigdy nie jest przeżywany bezpośrednio aktualnie w chwili swego śnienia się - istnieje tylko i jedynie jako wspomnienie. Stąd dziwny charakter specyficzny najpospolitszej jego treści. Dlatego to wspomnienia, których dokładnie zlokalizować w przeszłości nie możemy, przyjmują to właśnie specjalne zabarwienie sennych marzeń.] ${ }^{12}$ [WN 25]

Dopisek w nawiasie kwadratowym mamy prawo traktować jako komentarz wyrażający przekonania autora. Jak stwierdza Włodzimierz Bolecki, Witkiewicz utrzymywał swoje powieści w - zaczerpniętej od Tadeusza Micińskiego - konwencji „powieści-worka”, w której fabuła jest tylko pretekstem do wyłożenia własnych myśli, a w tok narracji może zostać wplecione wszystko, łącznie $z$ wypowiedziami publicystycznymi i rozprawą naukową ${ }^{13}$. „Recepta Stasia” polegała zatem prawdopodobnie na odtwarzaniu wydarzeń ze snu w odwrotnej kolejności, niż one w nim występowały. Zgadzałoby się to $\mathrm{z}$ myślą Freuda, który zwracał uwagę na fakt, iż człowiek zazwyczaj pamięta po przebudzeniu jedynie ostatnie fragmenty fantazji onirycznej, choć ma wrażenie, że trwała ona bardzo długo ${ }^{14}$. Czy rzeczywiście myśl austriackiego psychiatry była tu inspiracją, trudno ocenić na podstawie jednej wzmianki $z$ powieści wydanej 17 lat po zakończeniu przez Witkacego terapii psychoanalitycznej.

O tym, że pisarz raczej nie przekazywał Malinowskiemu metody utrwalania snów, przekonamy się dobitniej, jeśli przyjrzymy się notatkom na temat marzeń sennych w Dzienniku antropologa, które rzekomo miały zostać sporządzone zgodnie $z$ tą receptą ${ }^{15}$

ostatnia rozmowa ze Znam〈ierowskim〉. Spotkanie z parą w kaw〈iarni?〉 - rodzaj werandy czy też kon-

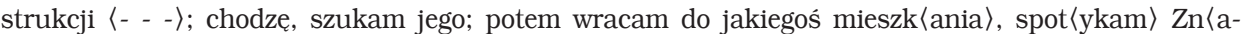
mierowskiego〉, rozm〈owa〉 na schodach, czy obok. Bardzo mile, o jakimś przyjęciu na drugi dzień w polish circle o $3000\langle--\rangle$. Uczucia: czuję, że jestem $\langle--\rangle$, Znam〈ierowski $\rangle$ jest miły. - Obok tego

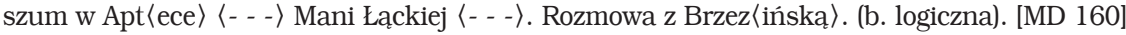

Tak przedstawia się sen, który Malinowski notuje pod datą 11 VIII 1912, zaraz po wzmiance o „recepcie Stasia”. Gdyby Witkacy miał wtedy własną technikę rejestrowania fantazji onirycznych, musiałaby ona w jakiś sposób wiązać się z teorią psychoanalityczną, ze względu na odbywana w tym czasie terapię u de Beauraina. Forma w zacytowanym śnie Malinowskiego różni się jednak od tej, którą propono-

Nawias kwadratowy pochodzi od Witkacego. Artysta miał zwyczaj wprowadzać w ten sposób do swoich powieści liczne wtrącenia i dygresje.

13 W. Bolecki, Poetycki model prozy $w$ Dwudziestoleciu międzywojennym: Witkacy, Gombrowicz, Schulz i inni. Studium z poetyki historycznej. Wyd. 2, popr. i uzup. Kraków 1996, s. 64-65.

15 Wyboru marzeń sennych z Dzienników zakopiańskich Malinowskiego, szczególnie naznaczonych inspiracja psychoanalizą Freudowską, dokonali twórcy antologii Od Jekelsa do Witkacego (s. 613618). D y bel omawia je też w pierwszej części książki Psychoanaliza-ziemia obiecana? (s. 210-212). 
wał Freud, chcący, by marzenie senne zapisywać możliwie dokładnie, ze wszystkimi skojarzeniami, jakie przychodzą na myśl w związku z nim. Tu natomiast częściej niż w innych partiach Dziennika używane są skróty, skąd należy się domyślać, że były to notatki dokonywane w pośpiechu. Świadczy o tym również nagromadzenie fragmentów nieczytelnych, niepewnych, na co zwróciła uwagę Kubica ${ }^{16}$.

Nieco inaczej prezentują się późniejsze marzenia senne Malinowskiego, choćby te, które przyszły antropolog spisał w październiku 1912. W środę $16 \mathrm{X}$ notuje dwa sny z udziałem Ireny Solskiej, słynnej aktorki młodopolskiej, z którą Witkacy miał wcześniej burzliwy romans. Pierwszy z nich jest krótki, typowo erotyczny (zob. MD 225-226). W drugim, znacznie bardziej złożonym, pojawia się prócz Solskiej jej mąż Ludwik oraz kilka innych osób. Malinowski drobiazgowo zapisuje wszystkie zapamiętane szczegóły: „okno po lewej stronie”, „Irenka na prawo” (MD 227), „landszaft, paprocie, jakaś młaka czy kałuża, księżyc się odbija; pode mną dolinka, na dnie staw [...]" (MD 228). Notuje, że tego ranka spał długo, a po przebudzeniu przypominał sobie swój sen (zob. MD 227), co z pewnością odnosi się do wzmiankowanej wcześniej „recepty Stasia”. W przypadku tego marzenia onirycznego rzuca się w oczy skrupulatność opowiadania, zgodna z zaleceniami Freuda. Czyżby więc Witkiewiczowska metoda zawierała również dyrektywy co do sposobu zapisu snów? Przeczyłby temu sen wcześniej przytoczony, nakreślony przez Malinowskiego wyjątkowo lakonicznie. Być może, Witkacy w swojej recepcie zawarł Freudowski nakaz dokładności, lecz akcentował inne aspekty? A może jego przyjaciel po prostu nie stosował się do owej rady? Na podstawie dostępnych dziś materiałów nie da się tego rozstrzygnać.

Niełatwo również stwierdzić, czy poglądy młodego Witkiewicza na temat snów były w roku 1912 identyczne $z$ Freudowskimi. $Z$ pewnościa jego wiedza o teoriach psychoanalitycznych mogła ulec jakimś przekształceniom, jeśli weźmiemy pod uwagę ich nieortodoksyjne traktowanie przez doktora de Beauraina. Mało prawdopodobne jednak, by postrzeganie snów przez pisarza nie miało żadnego związku z psychoanalizą Freuda. Jej echa pobrzmiewają bowiem w próbach, jakie podejmuje Malinowski w Dzienniku, by objaśnić znaczenie poszczególnych elementów w swych marzeniach sennych. Jako że $z$ dziełami austriackiego psychiatry bezpośrednio zetknął się dopiero później ${ }^{17}$, te psychoanalityczne wpływy musiał zaczerpnąc albo od Witkacego, albo od de Beauraina, $z$ którym również się znał ${ }^{18}$. W notatce Malinowskiego z 18 X 1912 czytamy: „St〈aś〉 o snach: przytłumione, przykre kompleksy występuja" (MD 232). Stwierdzenie to jest bardzo bliskie myśli psychoanalitycznej. Przy śnie zapisanym 31 X antropolog wspomina zaś o „kompleksie Boraina” (czyli Beauraina), co jednoznacznie kojarzy się $z$ koncepcją „kompleksu embriona” zakopiańskiego doktora, o której musiał słyszeć od młodego Witkiewicza ${ }^{19}$.

Zarówno Witkacy, jak i Malinowski orientowali się z pewnością w poszczególnych ustaleniach Freuda dotyczących objaśniania marzeń sennych. Zaświadcza o tym

16 Kubica, op. cit., s. 147.

17 Zob. ibidem, s. 147.

18 D y bel (op. cit., s. 210) ustalił, że Malinowski i de Beaurain działali razem w założonej w 1911 roku Sekcji Ludoznawczej Towarzystwa Tatrzańskiego. 
fragment notatki z 16 X 1912: „opow〈iadam〉 Stasiowi sen: czy Ir〈enka〉 występ〈uje〉 dlatego, że byłem $z$ nią dużo, a potem suddenly cut off 〈nagle przerwa〉? Czy substytucja; czy mi się podobała?" (MD 229). Przyjaciele wspólnie rozważają zatem hipotezy dotyczące znaczenia obecności Solskiej w dwóch snach zapisanych tego samego dnia: „ciagłe jej powracania we śnie, kiedy na jawie nie dałem jej ani $1 / 2$ myśli” (MD 228). Malinowski zaznacza, że nie pożądał jej ani w ogóle nie poświęcił jej chwili uwagi. Co więcej, nie pociagała go nawet w stanie onirycznym: „[jestem] świadomy, że jej nie kocham i że mi się nie podoba; ona mówi: to nic, ja wiem, że Ci się nie podobam, ale to będzie tym lepiej [...]" (MD 225-226). Antropolog podaje trzy wytłumaczenia: po pierwsze, obecność Solskiej w tych snach może wynikać z częstego początkowo widywania jej i nagłego urwania się kontaktów; po drugie, niewykluczone, że objawia się tu działanie mechanizmu substytucji; po trzecie, zachodzi ewentualność, że aktorka podoba się Malinowskiemu nieświadomie. Wszystkie trzy rozwiązania można wyprowadzić z teorii Freuda.

Młodzieńcze zapiski Malinowskiego dowodzą zatem bezsprzecznie, że psychoanaliza $z$ pewnością wpłynęła na podejście Witkiewicza do snów ${ }^{20}$, że znał on przynajmniej część ustaleń Freuda dotyczących ich objaśniania oraz że jego zainteresowanie tym kierunkiem psychologii rozpoczęło się w 1912 roku.

Podobnie jak Malinowski, autor Nienasycenia również zapisywał swoje sny ${ }^{21}$. Niestety, w jego przypadku nie dysponujemy tak obszernym świadectwem jak Dziennik $w$ ścistym znaczeniu tego wyrazu. Witkacy zrelacjonował natomiast kilka swoich marzeń onirycznych w listach do Czerwijowskiej, z którą korespondował właśnie $\mathrm{w}$ latach przechodzenia terapii $\mathrm{u}$ de Beauraina. Forma epistolarna naturalnie wymusiła na artyście pewną obróbkę materiału. Jeśli nawet młody Witkiewicz stosował się w prywatnych zapiskach do zaleceń Freuda, aby marzenie senne notować ze wszystkimi szczegółami i skojarzeniami, konwencja epistolarna bez wątpienia takiej drobiazgowości nie wymagała, dlatego też w tym wypadku ograniczał się jedynie do wzmiankowania o ich ogólnej treści. Najprawdopodobniej jednak autor Nienasycenia nie posługiwał się żadną konkretną techniką zapisywania snów - miał tylko metodę ich przypominania sobie.

\section{Sen o „mieduwalszczykach”}

Ze szczegółowych opisów marzeń sennych nakreślonych piórem Witkacego znamy jedynie te, które zawarł on w swoich powieściach. Najważniejszy wydaje się wnikliwie przedstawiony i omówiony na kartach Nienasycenia sen, który przypomina sobie Genezyp Kapen na poczatku utworu. To skrupulatnie opowiedziana, rozbudowana fantazja o tym, jak bohater idzie ulica przez nieznane miasto $\mathrm{z}$ kuzynem

Tak samo twierdzi Dy b el (op. cit., s. 208): „Terapia u de Beauraina musiała [...], tak czy inaczej, oddziałać na kształt późniejszej twórczości literackiej Witkacego. Dzięki niej bowiem zapoznał się on od strony praktycznej z pewnymi istotnymi elementami Freudowskiej teorii, które starał się później wykorzystać artystycznie. Należały do nich np. technika luźnej asocjacji i związane z tym gry słowne, szczególne znaczenie przypisywane marzeniom sennym, podkreślenie kluczowej roli seksualności w życiu psychicznym, krytyczny stosunek do kulturowych reguł i konwencji, specyficzny typ refleksji nad sobą". 
Toldziem i obcym „drabem”, którego twarzy zobaczyć nie może. Razem z towarzyszami wchodzi do kawiarni. Tam „drab” zaczyna go ściskać i obwieszcza Genezypowi, że jest jego bratem Jaguarym (tymczasem protagonista powieści ma jedynie siostrę). Młodzieniec odczuwa do „draba” olbrzymi wstręt i zabija go poprzez uduszenie. Nie czuje żalu, lecz trwogę przed konsekwencjami tego czynu. Chce uciec, ale drogę zagradzają mu żandarmi, wśród których rozpoznaje swoją matkę. Ta oświadcza, że wysłucha go „szef”. Na zakończenie snu wydarza się coś osobliwego: rodzicielka podaje Genezypowi kartkę ze zdaniem złożonym z neologizmów: „Mieduwalszczycy skarmią na widok czarnego beata, buwaja piecyty" (WN 27). Nie byłoby w tym nic dziwnego - częste występowanie w snach dziwacznych tworów językowych i kontaminacji słownych podkreślał w swoich pismach Freud ${ }^{22}$, o czym Witkacy mógł wiedzieć - gdyby nie fakt, że to samo zdanie zostało wykorzystane 9 lat przed opublikowaniem Nienasycenia, jako motto powstajacego w okolicach 1921 roku Bezimiennego dzieła, dramatu poświęconego Malinowskiemu. W dodatku zostało ono tam opatrzone dopiskiem: „ze snu z r. 1912” (WD 347). Ta okoliczność każe postawić pytanie, czy sen Genezypa Kapena nie jest aby snem samego autora.

Janusz Degler w książce Witkacego portret wielokrotny ustalił, że tworzenie powieści, która w 1930 została wydana jako Nienasycenie, artysta rozpoczął właśnie w 1912 roku. Poświadczaja to listy do Czerwijowskiej oraz wywiad udzielony przez Witkacego łódzkiemu dziennikowi „Republika” po prapremierze sztuki Persy Zwierżontkowskaja ${ }^{23}$. Istnieje zatem prawdopodobieństwo, że sen Genezypa Kapena z Nienasycenia jest reminiscencją autentycznego marzenia onirycznego Witkacego, zanotowanego w trakcie terapii psychoanalitycznej w 1912 roku. Wszystko na to wskazuje: pierwotny tytuł Nienasycenia brzmiał przypuszczalnie Obłęd ${ }^{24}$ (ostatecznie został tak nazwany drugi tom powieści), co nawiązuje do głębokiego kryzysu psychicznego, który Witkacy przeżywał w tym czasie, gdy poddał się psychoanalizie $\mathrm{u}$ de Beauraina. Doktor wypytywał go m.in. o fantazje senne, co wzbudziło w artyście zainteresowanie nimi. $Z$ informacji podanej w Bezimiennym dziele wynika, że niezrozumiałe zdanie powracające później w Nienasyceniu pochodzi ze snu z tego okresu. Hipotezę o wykorzystaniu własnych fantazji onirycznych zdaje się potwierdzać jeszcze fakt, iż Witkacy wielokrotnie wprowadzał elementy autobiograficzne do swoich dzieł, na co zwracali mu uwagę jego bliscy, chociażby w związku $z$ nieopublikowana za jego życia powieścią 622 upadki Bunga, czyli Demoniczna Kobie$t^{25}$, która powstała nieco wcześniej, bo w latach 1910-1911 ${ }^{26}$. W kolejnych utworach prozatorskich Witkiewicz lubił powracać do wątków i wydarzeń zawartych w swoim młodzieńczym dziele - niewykluczone zatem, że marzenie senne w Nienasyceniu wywiódł również ze swojego doświadczenia. Wątpliwe oczywiście, by zapisał je słowo w słowo tak samo jak w 1912 roku. Z powodu braku dostępu do osobistych

Fre u d, op. cit., s. 258-259.

J. D e g le r, Witkacego portret wielokrotny. Szkice i materiały do biografii (1918-1939). Warszawa 2009, s. 199.

Zob. ibidem, s. 206.

Pierwowzory postaci występujących w powieści rozszyfrowała A. Micińska (zob. jej wstęp w: S. I. Witki ewi c z, 622 upadki Bunga, czyli Demoniczna kobieta. Oprac. A. Micińska. Posł. J. D e gle r. Warszawa 2015, s. 28).

Zob. ibidem, s. 6-8. 
notatek młodego Witkiewicza dotyczących jego marzeń onirycznych trudno stwierdzić, w jakim stopniu zostało ono zainspirowane przez autentyczną fantazję.

Poza szeregiem neologizmów Witkacy przeniósł ze swojego życia do snu Genezypa z Nienasycenia jeszcze jedno. W liście do Czerwijowskiej z lutego 1913 artysta stwierdza: „Jestem znowu wolnym, ale każdą sekundę muszę zużyć na ostateczną walkę ze zmartwychwstałym s o b o w tó r e m”27. W powieści określenie „sobowtór” pojawia się w odniesieniu do nieświadomej natury głównego bohatera wiele razy tak samo zreszta w 622 upadkach Bunga. W Nienasyceniu Genezyp często myśli o wewnętrznym „drabie”, który czasem kieruje jego poczynaniami wbrew jego woli. Ów „drab” występuje także w przytoczonym śnie: „idzie z nim jakiś nie znany mu, wysoki i barczysty drab z ciemnoblond broda" (WN 26).

Bez wattpienia „drab” odpowiada bezrefleksyjnej, instynktownej naturze, która zauważa w sobie Zypcio również na jawie. We śnie ma zatem miejsce projekcja jego własnych cech na inna postać - zjawisko opisane przez Freuda ${ }^{28}$. Potwierdzeniem tego jest niemożność ujrzenia twarzy tajemniczego osobnika - cenzura senna chroni świadomość Genezypa przed rozpoznaniem samego siebie. Bohater symbolicznie zabija we śnie swojego brata-sobowtóra, którego obecności się boi - spycha go do nieświadomości. Jednocześnie scena ta stanowi antycypację późniejszego zdarzenia, kiedy główny bohater powieści, doprowadzony przez perwersyjną kochankę Persy Zwierżontkowską do nienasycenia graniczącego $z$ obłędem, daje się wreszcie ponieść swojej drugiej naturze i zabija młotkiem przypadkowego człowieka.

Freud w Objaśnianiu marzeń sennych wyraża myśl, że skoro sen ukazuje życzenie jako spełnione, to w tym sensie może zapowiadać przyszłe działania człowieka ${ }^{29}$. W innym miejscu przytacza wszakże cytat z Platona: „dobrzy są ci, którzy poprzestają na tym, aby śnić o rzeczach, które inni, źli - czynią"30. W momencie zrzeczenia się swojej świadomości na rzecz „draba” Genezyp dołącza do tej drugiej grupy - Nienasycenie stanowi przenikliwe studium psychologiczne ukazujące przebieg owej przemiany.

Morderstwo dokonane przez bohatera we śnie jest spełnieniem życzenia nieświadomości - wyrazem pragnienia, aby dać upust bezrefleksyjnemu instynktowi. Pojawienie się żandarmów wydaje się natomiast efektem działania cenzury sennej, która chce ukarać śniącego za nieetyczne żądze. Matka i osobliwe zdanie zapisane na kartce sprawiają wrażenie próby pogodzenia owych sprzecznych dążeń. Aby odgadnąć, o co miałoby chodzić w tej syntezie, należałoby przetłumaczyć neologizmy na zrozumiały język. W świetle metody Freuda konieczne byłoby przepytanie pacjenta, co poszczególne słowa mogą dla niego znaczyć. Badacz zalecał, by stosować przy tym metodę luźnych skojarzeń, w celu dojścia do ukrytej treści marzenia sennego ${ }^{31}$. $Z$ oczywistych względów nie jesteśmy w stanie odbyć rozmowy ani $z$ Witkacym, ani z Genezypem Kapenem. Jednak, być może, autor powieści zawarł w niej wskazówki dotyczące sensu tych tworów wyrazowych?

Witkiewicz, Listy I, s. 243.

Fre u d, op. cit., s. 279.

Ibidem, s. 519.

S. Freud, Wstęp do psychoanalizy. Przeł. S. Ke mpnerówna, W. Zaniewicki. Wyd. popr. i uzup. Kęty 2010, s. 97.

Ibidem, s. 70-73. 
Bohaterowi Nienasycenia zdanie ze snu kojarzy się z pytaniem egzaminacyjnym, na które nie zna się odpowiedzi (WN 23). Niedługo wcześniej zdał maturę, co stanowi z pewnością źródło tego skojarzenia. $\mathrm{W}$ toku narracji zostaje powiedziane, że owo marzenie senne rozerwało „skorupę konwencjonalnych "szkolnych" tajemnic" (WN 23) i ukazało kryjący się pod nią dwoisty sens życia. Sen prowadzi Genezypa do refleksji dotyczącej tajemnicy jego istnienia, związanej z niewytłumaczalna zagadka, jaka jest poczucie własnego ,ja” - wyodrębnionego ze świata, a jednocześnie pozwalającego na jego percypowanie (WN 24). W toku rozmyślań bohater postanawia poznać ową tajemnicę, antycypując tym samym swoje przyszłe losy nienasyceńca. Wobec niemożności zaspokojenia nieskończonego pragnienia doświadczenia Tajemnicy Istnienia popada on w obłęd i zatraca świadomość, która to pragnienie wywołała (WN 28-29). Przy okazji omawiania snu Genezypa wyraża Witkiewicz ewidentnie psychoanalityczne spostrzeżenie:

treść jego [tj. snu] istotna, nieuchwytna i niewyrażalna, zatracała się w konkretności wspominanych wydarzeń, dając ledwie znać o jakimś drugim, niedościgłym, znikającym na krańcach świadomości, życiu. [WN 26]

Znaczenia tych niedostępnych dla ,ja” Genezypa treści psychicznych można się domyślać - zgodnie z metodą Freuda - po skojarzeniach, które przytacza w powieści sam bohater. $\mathrm{W}$ związku $\mathrm{z}$ dokonanym we śnie zabójstwem przychodzi mu na myśl krew. Genezyp dziwi się sobie, ponieważ w marzeniu sennym krwi wcale nie było (WN 25). Przyczyna owej konotacji nie zostaje wyjaśniona. Narrator oświadcza jedynie, że Genezyp dostrzegł „ostatnie ogniwo popełnionej zbrodni i dalej jeszcze, tajemniczy jej początek, gubiący się w czarnej nicości sennego niebytu" (WN 25). Wobec niezrozumiałości tej fantazji młody Kapen zdradza swoją zależność od matki, co objawia się w chęci poskarżenia się jej, iż „sny są straszne i że w życiu kryją się zasadzki okropne [...]" (WN 28). Daje tu o sobie znać nie do końca uświadomiony kompleks matki, którą bohater darzy sprzecznymi uczuciami „dzikiego przywiązania i pogardy" (WN 30). To jednoznacznie odsyła nas do teorii Freuda mówiącej o występowaniu w snach afektów antynomicznych skierowanych do bliskich osób, przy czym afekty negatywne są niekiedy reliktami z przeszłości - pozostałościa po wypartym ze świadomości urazie ${ }^{32}$. Ponadto Genezyp przypomina sobie także poznanego poprzedniego dnia kompozytora Tengiera ${ }^{33}$ oraz przede wszystkim - księżną Irinę Wsiowołodownę Ticoderoga, która miała się później stać jego kochanką, a przy tym symbolem niezgłębialności Tajemnicy Istnienia.

Rozważania Genezypa na temat znaczenia snu dobrze podsumowuje następujący fragment powieści:

I nagle tajemnica snu tego i erotycznej przyszłości stała się tajemnicą wszystkiego - ogarnęła świat cały i jego samego. Nie była to już niezrozumiałość każdej chwili życia z osobna - była to niedocieczona tajemnica całego wszechświata, Boga i wklęsłości niebieskiej filiżanki. Ale znowu nie jako problem

Genezyp przywołuje w pamięci słowa Tengiera, lecz z treści powieści nie można wywnioskować, czy były to te same wyrazy, które bohater usłyszał we śnie. Wysoce prawdopodobne jednak, że zdanie z marzenia sennego w jakiś sposób się do nich odnosiło: „Słowa jego [tj. Tengiera], słyszane wczoraj (i nie zrozumiane), stały się nagle jasne w całości jako niezanalizowana masa, raczej tylko ich ton ogólny. O sensie pojecciowym nie było nawet mowy” (WN 23). 
wiary czy niewiary postawiony na zimno. Wszystko to żyło i działo się jednocześnie, a przy tym marzło w nieruchomości absolutnej, zamierało w oczekiwaniu jakiegoś cudu nie do pomyślenia, objawienia ostatecznego, poza którym nie byłoby już nic - chyba sama najdoskonalsza, najcudowniejsza, nie dająca się w żaden sposób wyobrazić Nicość. [WN 29]

Marzenie senne stawia przed Genezypem fundamentalne problemy dotyczące istnienia świata, wiary w Boga i natury świadomości ludzkiej. Dochodzimy tu do zasadniczego rysu odróżniającego poglądy Witkacego na temat snów od myśli Freuda. To, co twórca psychoanalizy potraktowałby jako wynik potrzeb seksualnych, Witkiewicz uważa za przejaw pragnienia bardziej pierwotnego, nadrzędnego wobec tęsknot erotycznych, które jednak mogą być przyczyną jego rozbudzenia. W odniesieniu do spraw psychicznych pisarz nie uznawał - panującego w teorii psychoanalitycznej - panseksualizmu, czemu wielokrotnie dawał wyraz. Jak podaje Maciej Soin w monografii dotyczącej filozofii Witkacego, według autora Nienasycenia erotyzm stanowił „pierwotny sposób potwierdzania swojego istnienia przez indywiduum"34. W tym sensie sztuka, religia i filozofia sa jego pochodnymi - nie dlatego jednak, że miałyby być rodzajem sublimacji popędu seksualnego, lecz dlatego, że spełniają podobne zadanie: odpowiadają na fundamentalną nieprzystawalność człowieka do rzeczywistości, wyrażaja jego zdumienie Tajemnicą Istnienia. $Z$ tego też powodu Witkacy sprzeciwiał się stwierdzeniom Malinowskiego - analogicznym do Freudowskich - w odniesieniu do pochodzenia uczuć religijnych. Zdaniem pisarza, są one następstwem metafizycznego nienasycenia wynikającego z konstytutywnego dla człowieka wyodrębnienia ze świata i związanego $\mathrm{z}$ nim poczucia zadziwienia ${ }^{35}$.

Czy zatem sen Genezypa o „mieduwalszczykach” w swoim najgłębszym znaczeniu wyraża metafizyczny głód bohatera wynikający z rozbudzenia się u niego poczucia własnego ,ja”? Witkiewicz pisze: „Okazało się, że ludzie nie są znowu tak wielkim bydłem i że bez idei żyć im trudno" (WN 44). Podobnie trudno jest głównemu bohaterowi powieści, rozpaczliwie starającemu się czymkolwiek zapełnić brak transcendentnej zasady, która pokierowałaby jego życiem. Takie wytłumaczenie omawianego marzenia sennego można poprzeć wskazówkami zawartymi w Bezimiennym dziele.

Jak dowiadujemy się $z$ treści dramatu, Witkacy mianem „mieduwalszczyków” obdarzył wyznawców niejakiego Joachima Mieduwała. Grupa ta zamierza wprowadzić nowy rodzaj teokracji, stworzyć sztuczną religię, która zaspokoi dążenia mas. Ich przywódca Cynga głosi: „To, co nie udało się innym kościołom z powodu istotnej wiary i kompromisów z tą wiarą, my zrobimy świadomie, jako pragmatyczny, programowy humbug...” (WD 369). Stwierdza, że ludzkości nie wystarczy idea odnosząca się tylko do ziemskiej rzeczywistości, jak np. komunizm, lecz musi być ona oparta na metafizyce:

M. S o i n, Filozofia Stanisława Ignacego Witkiewicza. Wyd. 2. Wrocław 2002, s. 46-47.

Jak pisze D. C. G e r o u ld (Stanisław Ignacy Witkiewicz jako pisarz. Przeł. I. Si e r a dzki. Warszawa 1981, s. 29): „W rozumieniu Witkacego religia stanowiła w dawnych czasach jeden z głównych sposobów reakcji na rzeczy niewiadome, metafizyczną próbę odpowiedzi na samotność człowieka we wszechświecie, a nie, jak uważał Malinowski, coś, co można wyjaśnić rzekomo naukowymi przyczynami materialnymi, jak popęd płciowy czy głód”. 
Trzeba dać syndykatom prawdziwą, fikcyjną religię, a nie substytut w rodzaju mitu o generalnym strajku. Wierz mi pan, że dzisiejsi ludzie są daleko skłonniejsi do jakiejkolwiek wiary niż totemiści na Nowej Gwinei. [WN 369]

Nie tylko postacie „mieduwalszczyków” wiążą Bezimienne dzieło z Nienasyceniem. W akcie trzecim Plazmonik oświadcza Róży, którą darzy nieszczęśliwą miłością: „To jest wszystko głupi, ohydny sen” (WD 399), po czym w akcie czwartym zabija ją z zimną krwią, bez śladu jakichkolwiek uczuć. Wydarzenie to przypomina analogiczną scenę $z$ powieści, kiedy Genezyp dokonuje bezsensownego mordu, doprowadzony do granic swych możliwości w obywaniu się bez zaspokojenia popędów. Tam ofiarą pada przypadkowy mężczyzna - niejako w zastępstwie za szaleńczo pożądana przez bohatera Persy Zwierżontkowską.

$\mathrm{Na}$ zakończenie objaśniania wątku „mieduwalszczyków” wypada powrócić do pytania o to, czy przedstawiony w Nienasyceniu sen da się utożsamić z marzeniem onirycznym samego autora utrwalonym w 1912 roku podczas odbywania terapii psychoanalitycznej. Jest to prawdopodobne, lecz nie można ocenić, w jakim stopniu ustęp powieści wydanej w 1930 roku pokrywa się z młodzieńczą notatką. Bezsprzecznie jakiś zapisek musiał istnieć (dowodzi tego motto Bezimiennego dzie$\nmid a$ ), a autentyczna fantazja musiała wpłynąc na kształt snu Genezypa Kapena, choćby tylko jako pierwotne źródło zdania złożonego z niezrozumiałych neologizmów. Nie jest tajemnica, że Witkacy w jakiś sposób utożsamiał się $z$ tym bohaterem, ponieważ - jak zauważa Degler - swoją pierwszą ukończoną powieść, 622 upadki Bunga, zamierzał wydać właśnie pod pseudonimem „Genezyp Kapen”36. Postanowił to w czasie, gdy istniały już zręby utworu opublikowanego później jako Nienasycenie, najprawdopodobniej m.in. fragmenty pierwszego tomu ${ }^{37}$, a więc, być może, również sen o „mieduwalszczykach”. O tym, że doświadczenia, które spotykają bohatera we śnie, mają jakiś związek $z$ przeżyciami autora, przekonuje ponadto pojawienie się w powieści „draba” - wewnętrznego sobowtóra Genezypa Kapena.

$\mathrm{Na}$ podstawie zaprezentowanych tu analiz można bez wątpienia potwierdzić, że zwiększone zainteresowanie Witkacego snami nastąpiło dzięki jego zetknięciu się $\mathrm{Z}$ psychoanalizą. $\mathrm{Z}$ początku była to fascynacja połaczona $\mathrm{z}$ dużą dozą rezerwy, później jednak artysta przekonał się do wielu założeń tej teorii i przyjął je jako własne.

Od roku 1912, kiedy rozpoczął terapię u de Beauraina, Witkacy zapisywał swoje marzenia senne. Choć notatki owe nie zachowały się, sny z pewnością zajmowały jego uwagę, szczególnie w latach 1912-1913, o czym świadczą Dziennik Malinowskiego oraz listy Witkacego do Czerwijowskiej. Dzięki tym materiałom wiadomo, że autor 622 upadków Bunga miał swoją własną metodę przypominania sobie snów. Jak możemy przypuszczać na podstawie odautorskich przemyśleń zawartych w Nienasyceniu, technika ta oznaczała najprawdopodobniej odtwarzanie wydarzeń mających miejsce w marzeniu sennym w odwrotnej kolejności niż ta, w której one wystąpiły. Niewykluczone, że kryje się za tym inspiracja teorią Freuda, 
lecz nie da się tego stwierdzić na pewno. Nic nie wskazuje na to, aby recepta na przypominanie snów wiązała się też z metodą ich utrwalania.

Choć opis sennego marzenia Genezypa Kapena ujawnia silne nacechowanie wpływami psychoanalizy, znaczenie tej fantazji onirycznej dla psychiki bohatera powieści wykłada Witkacy w sposób niezupełnie zgodny z założeniami teorii psychologicznej Freuda. Objaśnienie snu o „mieduwalszczykach” uwidacznia rysy charakterystyczne dla specyficznych Witkiewiczowskich poglądów na temat ludzkiej psyche. Zdaniem pisarza, człowieka dręczy poczucie dziwności bytu, Tajemnica Istnienia, co powoduje w nim wieczne nienasycenie. Pojawiające się we śnie osobliwe słowa stanowią dla Genezypa odzwierciedlenie zagadki świata i sekretu własnego „ja”. Sen wyraża potrzebę znalezienia idei, która wytyczy jego życiu kierunek wobec wielkiej niewiadomej. Ten aspekt znaczenia marzenia sennego sprawia, że myśl Witkacego o snach ma charakter oryginalny, autorski, choć bez wątpienia została zainspirowana przez teorię Freuda oraz jej wariant w postaci poglądów de Beauraina ${ }^{38}$.

Abstract

FRYDERYK NGUYEN University of Wrocław

\section{INTERPRETATION OF DREAMS ACCORDING TO STANISEAW IGNACY WITKIEWICZ}

Stanisław Ignacy Witkiewicz familiarised with psychoanalysis when he underwent a therapy at Karol de Beaurain's and it is at that moment when his fascination with dreams increased. The artist developed his own method of recollecting occurrences which consisted in evoking them in reverse order in comparison to that in dreaming. Though Witkacy initially rejected Sigmund Freud's thought, with time he became its supporter, and the description of Genezyp Kapen's dream in Nienasycenie (Insatiability) is deeply influenced by it. An in-depth analysis of this oneiric phantasy reveals original traces of Witkiewicz's views on the nature of human psyche. The main source of human struggle is, according to him, initial amazement with Mystery of Existence. w Pożegnaniu jesieni) mogłoby ukazać, jak rozwijały się jego poglądy dotyczące marzeń sennych i jakim przemianom ulegały literackie fantazje oniryczne pisarza, w miarę jak zapoznawał się on z psychoanalizą. 